Cybernetics: Journal Educational Research and Social Studies

Volume 2, Nomor 4, Oktober 2021

Journal Homepage: http://pusdikra-publishing.com/index.php/jrss

\title{
Peranan Badan Penasihat Pembinaan dan Pelestarian Perkawinan (BP4) Dalam Membentuk Keluarga Sakinah Mawaddah Warahmah Pada Masyarakat Kecamatan Panyabungan Selatan
}

\author{
Mawaddah', Maraimbang ${ }^{2}$, Sholahuddin Ashani ${ }^{3}$
}

Universitas Islam Negeri Medan

Corresponding Author :@ Mawaddahbornas@gmail.com

\begin{tabular}{|c|c|}
\hline & ABSTRACT \\
\hline & $\begin{array}{l}\text { Penelitian ini mengkaji tentang peranan badan penasihat pembinaan dan } \\
\text { pelestarian perkawinan dalam membentuk keluarga yang sakinah mawaddah } \\
\text { warahmah. Setiap pernikahan pada dasarnya memiliki keinginan dan keinginan } \\
\text { itu lebih banyak menjadi pernikahan yang sakinah mawaddah dan warahmah } \\
\text { (samawa). Bp4 Panyabungan selatan menyeleggarkan bimbingan nikah bekal } \\
\text { pengetahuan buat para calon pengantin agar terbentuknya keluaraga yang } \\
\text { harmonis dan keluarga yang samawa. Penelitian ini bertujuan untuk } \\
\text { mengetahui: 1). Mengetahui peran Bp4 dalam membimbing calon pengantin } \\
\text { untuk mewujudkan keluarga yang sakinah mawaddah dan warahmah. 2). Cara } \\
\text { atau metode yang dilakukan Bp4 dalam membangun keluarga sakinah } \\
\text { mawaddah dan warahmah di Kua desa Tanobato Kecamatan Panyabungan } \\
\text { Selatan. Dalam penelitian ini Bp4 sangat berperan penting dalam mewujudkan } \\
\text { keluarga yang samawa terutama di desa Tanobato dan sekitarnya termasuk juga } \\
\text { desa Lumban Dolok. Dampak dari bimbingan di Kua ini yaitu para calon } \\
\text { pasangan dapat memahami dan mengetahui materi bagaimana cata membina } \\
\text { keluarga yang baik sesuai agama islam dan dapat meningkatkan kualitas } \\
\text { perkawinan dan juga dapat mengurangi angkat perceraian di daerah tersebut }\end{array}$ \\
\hline & Peran Bp4, Pra Nikah, Keluarga Samawa \\
\hline
\end{tabular}

\section{PENDAHULUAN}

Keluarga yang kuat merupakan salah satu fondasi terpenting dalam pembangunan sumber daya manusia sesuai cita-cita luhur bangsa. Keluarga juga bisa diartikan sebagai salah satu komponen utama dari tercapainya pembangunan berkelanjutan. Kekuatan suatu bangsa sangat dipengaruhi oleh kekuatan keluarga. Masa depan bangsa sesungguhnya dibangun di atas kekuatan fondasi keluarga.

Mewujudkan keluarga yang kokoh dan tangguh itu sangat diperlukan ikhtiar sungguh-sungguh, teristimewa pada pasangan perempuan laki-laki yang akan dan sedang membangun mahligai rumah tangga. Pengetahuan tentang mewujudkan keluarga bahagia, kesadaran bersama dalam membangun keluarga sehat dan berkualitas, kesungguhan dalam mengatasi berbagai konflik keluarga, serta komitmen dalam menghadapi berbagai tantangan kehidupan global yang semakin berat.

Tanpa semua itu keluarga kokoh dan tangguh sangat sulit diwujudkan. Akibatnya, kehidupan perkawinan menjadi rapuh dan rentan mengalami konflik tak berujung dan berakhir dengan perceraian. Berbagai upaya untuk menekan angka perceraian telah dilakukan oleh berbagai pihak. Baik pemerintah maupun lembaga- 
lembaga non pemerintah telah melakukan beragam cara agar perceraian tidak mudah terjadi di kalangan masyarakat. Selain mediasi dan nasihat perkawinan yang senantiasa dilakukan oleh mediator di Pengadilan Agama dan Kua.

Kementerian Agama juga secara khusus menguatkan perkawinan melalui bimbingan perkawinan. Penguatan persiapan perkawinan tidak hanya diorientasikan pada penguatan pengetahuan saja, namun juga memampukan pasangan nikah dalam mengelola konflik dan menghadapi tantangan kehidupan global yang semakin berat. Upaya ini menjadi langkah strategis dalam memastikan sebuah bangunan rumah tangga yang akan diciptakan, dibangun di atas pondasi yang kuat dan kokoh. Untuk mewujudkan harapan tersebut tentu bukan sesuatu yang mudah. Untuk itu, diperlukan kesungguhan dan kerja sama dari berbagai pihak.

Kita sebagai manusia harus menyadari pentingnya kesiapan berumah tangga tersebut, setiap calon pengantin perlu mengikuti program bimbingan perkawinan. Untuk mencapai maksud tersebut, beberapa kebijakan baru terkait penyelenggaraan bimbingan perkawinan bagi catin atau calon pengantin. Di dalam Islam membatasi secara ketat beberapa praktik berkeluarga lainnya. Misalnya, membatasi jumlah istri dalam poligami dari tak terbatas menjadi maksimal empat dengan syarat adil dan disertai dorongan kuat untuk monogami. Perceraian yang boleh rujuk yang semula tak terbatas menjadi hanya boleh dua kali. Disamping itu, Islam juga memunculkan nilai yang baru untuk memperkuat keluarga. Misalnya menegaskan bahwa perkawinan adalah janjian kokoh (mitsaqan ghalizhan), perintah pergaulan yang layak (mu'asyarah bil$m a^{\prime} r u f$ ) antara suami dan istri, dan pengaitan ketaqwaan dan keimanan dengan perilaku dalam berkeluarga. Islam juga memberikan perempuan hak waris, dan hak sumpah untuk membatalkan sumpah suami yang menuduhnya berzina tanpa saksi, hak cerai gugat (khulu) dan hal lainnya.

Sayangnya beberapa sikap dan tindakan tidak manusiawi dalam kehidupan berkeluarga seperti masa jahiliyah ternyata masih dijumpai hingga hari ini. Misalnya perkawinan paksa, perjodohan antar anak, kekerasan rumah tangga, dan lain-lain. Sikap dan tindakan buruk semacam ini jelas mengancam sulitnya perkawinan yang kokoh dan keluarga bermartabat dan harmonis (sakinah) untuk terwujud. Calon pasangan suami istri perlu memiliki landasan dan bekal pemahaman yang cukup tentang kehidupan keluarga yang baik dan sesuai tuntunan agama. Hal ini meliputi perencanaan yang matang, tujuan yang jelas, dan bekal agar perkawinan bisa kokoh dan mampu melahirkan keluarga sakinah (Machrus, Adib, 2019). Permasalahan yang seringkali muncul di dalam rumah tangga adalah adanya percekcokan, perselisihan dan pertikaian. Beberapa hal yang mungkin menjadi penyebab terjadinya keretakan hubungan rumah tangga suami-isteri yaitu, masalah internal yang bersifat individu, faktor eksternal yang berupa pengaruh kehidupan lingkungan sekitar, dan faktor orang ketiga, yang biasanya berupa campur tangan orang tua yang terlalu mendalam.

Keluarga sakinah adalah keluarga yang diinginkan setiap pasangan dalam membina rumah tangga, kehidupan berkeluarga yaitu suatu yang bersifat fitrah. Sebagai masyarakat keluarga sakinah merupakan inti bagi proses perkembangan 
masyarakat-masyarakat terdiri dari unsur keluarga, keluarga berbentuk dari unsur individu. Maka bila anggota keluarga terdiri dari individu yang shaleh, keluarga tersebut dinyatakan sebagai keluarga sakinah. Dan jika masing-masing keluarga berbuat demikian, maka akan terciptalah masyarakat yang sehat, kuat serta mulia. Keluarga yang sakinah, mawaddah, warahmah adalah istilah sekaligus doa yang sering kali dipanjatkan dan diharapkan oleh para muslim yang telah menikah dan membina keluarga, khusus di Indonesia. Keluarga sakinah, mawaddah, dan rahmah tentunya bukan hanya sekedar semboyan belaka dalam ajaran Islam.

Makna keluarga sakinah mawahddah warahmah yaitu Sakinah yang berasal dari bahasa arab yang artinya yaitu ketenangan, ketentraman, aman atau damai. Lawan kata dari ketentraman atau ketenangan adalah keguncangan, keresahan, kehancuran. Sebagaimana arti kata itu tersebut, keluarga sakinah berarti keluarga yang didalamnya mengandung ketenangan, ketentraman, keamanan, dan kedamaian antar anggota keluarganya. Keluarga yang sakinah berlawanan dengan keluarga yang penuh keresahan, kecurigaan, dan kehancuran. Kita bisa melihat keluarga yang tidak sakinah contohnya adalah keluarga yang didalamnya penuh perkelahian, kecurigaan antar pasangan, bahkan berpotensi terhadap adanya konflik yang berujung perceraian. Ketidakpercayaan adalah salah satu aspek yang membuat gagal keluarga sakinah terwujud. Misalnya saja pasangan saling mencurigai, adanya pihak atau orang yang mengguncang rumah tangga atau perlawanan istri terhadap suami (Zaituna, Subhan, 2004).

Mawaddah berasal pula dari bahasa arab yang artinya adalah perasaan kasih sayang, cinta yang membara, dan menggebu. Mawaddah ini khususnya digunakan untuk istilah perasaan cinta yang menggebu pada pasangannya. Dalam Islam, mawaddah ini adalah fitrah yang pasti dimiliki oleh manusia. Muncul perasan cinta yang menggebu ini karena hal-hal yang sebabnya bisa dari aspek kecantikan atau ketampanan pasangannya, moralitas, kedudukan dan hal-hal lain yang melekat pada pasangannya atau manusia ciptaan Allah.

Kriteria calon istri menurut Islam dan kriteria calon suami menurut Islam bisa menjadi aspek yang perlu dipertimbangkan untuk memunculkan cinta pada pasangan nantinya. Adanya perasaan mawaddah pastinya mampu membuat rumah tangga penuh cinta dan sayang. Tanpa adanya cinta tentunya keluarga menjadi hambar. Adanya cinta membuat pasangan suami istri serta anak- anak mau berkorban, mau memberikan sesuatu yang lebih untuk keluarganya. Perasaan cinta itu harus bisa memberikan perasaan saling memiliki dan saling menjaga. Keluarga yang ada perasaan mawaddah tentunya memunculkan nafsu yang positif (nafsu yang halal dalam aspek pernikahan). Kita bisa melihat, keluarga yang tidak ada mawaddah tentunya tidak akan saling memberikan dukungan, hambar, yang membuat rumah tangga pun seperti sepi. Maknanya yaitu orang yang memiliki cinta di hatinya akan lapang dadanya, penuh harapan, dan jiwanya akan selalu berusaha menjauhkan diri dari keinginan buruk atau jahat. Dan senantiasa akan menjaga cintanya baik di kala senang maupun susah ataupun sedih. 
Rahmah berasal dari bahasa Arab yang artinya adalah ampunan, rahmat, rezeki, dan karunia. Rahmah terbesar tentu berasal dari Allah SWT yang diberikan pada keluarga yang terjaga rasa cinta, kasih sayang, dan juga kepercayaan. Keluarga yang rahmah tidak mungkin muncul hanya sekejap melainkan muncul karena proses adanya saling membutuhkan, saling menutupi kekurangan, saling memahami, dan memberikan pengertian (Machrus, Adib, 2019). Dengan prosesnya yang penuh kesabaran, karunia itu pun juga akan diberikan oleh Allah sebagai bentuk cinta tertinggi dalam keluarga. Rahmah tidak terwujud jika suami dan istri saling mendurhakai. Rasa kasih sayang ini menyebabkan seseorang akan berusaha memberikan yangbterbaik buat pasangannya.

Membangun keluarga memang tampak mudah kalau dilihat dengan mata kita saja, namun memelihara dan membina keluarga itu agar menjadi keluarga yang sakinah tidaklah mudah untuk mencapai tujuan pernikahan ini. Islam menempatkan berbagai patokan yang harus dilalui, direncanakan dan dilaksanakan mulai dari memelih pasangan hidup, penilaian terhadap calon suami atau istri, rukun dan syarat nikah, mahar dan sebagainya (Machrus, Adib,2019). Untuk mencapai keluarga yang sakinah, maka hak suami istri dan kewajiban masing-masing harus dilaksanakan dengan penuh keadilan, keserasian, keselarasan, dan keseimbangan baik dalam fungsi keagamaan maupun keduniaan. Ayat-ayat al-Quran yang mengatur masalah perkawinan dimulai dengan adanya penegasan bahwa Allah menciptakan makhluk hidup berpasangpasangan, baik dalam dunia manusia, hewan dan juga tumbuh-tumbuhan dan untuk memungkinkan terjadinya perkembangbiakan dan melangsungkan kehidupan jenis masing-masing.

Bp4 adalah suatu singkatan dari Badan Penasihatan, Pembinaan, dan Pelestarian Perkawinan adalah organisasi profesional yang bersifat sosial keagamaan sebagai mitra kerja Kementrian Agama dan Institusi terkait baik pemerintah maupun non pemerintah dalam mewujudkan keluarga sakinah mawaddah wa rahmah. Tujuan dari BP4 ini yaitu mempertinggi mutu perkawinan untuk mewujudkan keluarga sakinah sesuai ajaran islam untuk mencapai masyarakat dan bangsa indonesia yang maju, mandiri, bahagia, sejatera materil dan spiritual (Hasil Munas BP4 XV, 2014). Bp4 ini telah mendapat pengakuan resmi dari pemerintah yaitu dengan keluarnya Surat Keputusan Menteri Agama Republik Indonesia No. 85 tahun 1961 yang menetapkan BP4 sebagai satusatunya badan yang berusaha pada bidang penasehatan perkawinan jika terjadi perselisihan rumah tangga (perceraian).

\section{METODE PENELITIAN}

Jenis penelitian ini adalah penelitian lapangan (field research), yaitu penelitian yang dilakukan di lapangan guna untuk mengetahui dan juga memperoleh data dengan jelas tentang bagaimana peran BP4 Panyabungan Selatan Kabupaten Mandailing Natal dalam membimbing keluarga sakinah mawaddah warahmah (Lexy. J. Moleong, 1991). Penelitian ini juga didukung dengan penelitian pustaka (library research), yaitu penelitian yang dilakukan di perpustakaan dan dilangsungkan dengan membaca dan 
juga menelaah. Penelitian ini menjelaskan langsung bagaimana peran BP4 panyabungan selatan kabupaten mandailing natal dalam membimbing keluarga sakinah baik bimbingan pra nikah atau pasca nikah yang bertujuan agar terbentuknya keluarga yang sakinah mawaddah warahmah. Sumber data primer diperoleh dari sumber pertama melalui prosedur dan teknik pengumpulan data yang dilakukan seperti interview, observasi. Penulis memperoleh data dari observasi dan wawancara di BP4 Kecamatan Panyabungan Selatan kepala kua, penyuluh, tokoh agama yang berada di wilayah Desa Panyabungan Selatan dan warga yang melakukan pernikahan. Data sekunder diperoleh dari sumber tidak langsung yang biasanya berupa data dokumentasi dan arsip-arsip resmi.

\section{HASIL DAN PEMBAHASAN Bp4 dan Keluarga Samawa}

BP4 adalah suatu singkatan dari Badan Penasihatan, Pembinaan, dan Pelestarian Perkawinan adalah organisasi profesional yang bersifat sosial keagamaan sebagai mitra kerja Kementrian Agama dan Institusi terkait baik pemerintah maupun non pemerintah dalam mewujudkan keluarga sakinah mawaddah wa rahmah.

Tujuan dari BP4 ini yaitu mempertinggi mutu perkawinan untuk mewujudkan keluarga sakinah sesuai ajaran islam untuk mencapai masyarakat dan bangsa indonesia yang maju, mandiri, bahagia, sejatera materil dan spiritual (Hasil Munas BP4 XV, 2014). Bp4 ini telah mendapat pengakuan resmi dari pemerintah yaitu dengan keluarnya Surat Keputusan Menteri Agama Republik Indonesia No. 85 tahun 1961 yang menetapkan BP4 sebagai satu-satunya badan yang berusaha pada bidang penasehatan perkawinan jika terjadi perselisihan rumah tangga (perceraian).

BP4 berada dalam struktur Departemen Agama, khususnya di bawah Direktur Urusan Agama dan Pembinaan Syari'at. Pada Kementerian Agama terdapat BP4 pusat yang membawahi BP4 Tingkat Provensi, kemudian BP4 tingkat kota, dan lingkup terkecil adalah tingkat kecamatan yang berada di setiap Kantor Urusan Agama (KUA). BP4 berdiri sebagai bentuk keperhatinan dan kepedulian terhadap kualitas perkawinan umat Islam di Indonesia.

Lembaga BP4 yaitu lembaga yang berusaha memberikan pelayanan terhadap persoalan keluarga sebagai mitra kementrian agama seperti berikut : memberikan bimbingan pernikahan dengan menyelenggarakan kursus calon pengantin, mengembangkan pembinaan keluarga sakinah, memberikan pendidikan pra nikah dan pasca nikah (Peraturan Dirjen Bimas Islam Nomor Dj.II/542/tahun 2013.)

a. Menyelenggarakan kursus calon pengantin

Dalam agama Islam ini adalah sunnah Rasulullah SAW. maka ketentuan tentang perkawinan diatur dalam undang-undang. Tujuan perkawinan tentunya ingin membangun rumah tangga yang sakinah, mawadah warahmah. Supaya apa yang diharapkan suami isteri atau calon pengantin dapat dicapai, maka perlu adanya pengarahan dan perbekalan sebelum mereka melangsungkan pernikahan ataupun bimbingan. Di BP4 inilah masyarakat dapat berkonsultasi tentang 
Cybernetics: Journal of Research and Educational Studies

Volume 2 Nomor 4, Oktober 2021

Halaman 54-65

masalah yang berkaitan tentang perkawinan baik pra nikah atau pasca nikah melalui kursus calon pengantin.

b. Mengembangkan pembinaan keluarga sakinah

Para pasangan suami isteri dalam mengarungi bahtera rumah tangga tidak selamanya berjalan lancar tanpa ada rintangan, kadangkala badai menerpa sehingga memungkinkan terjadinya perselisihan dalam rumah tangga. Misalnya perselingkuhan, ketidakadilan, cemburu buta, poligami dan lain-lain.

c. Memberikan pendidikan pra nikah dan pasca nikah dan pemudi yang belum melangsungkan pernikahan perlu kiranya untuk mendapat pengetahuan tentang pernikahan sejak mereka masih duduk di bangku sekolah SLTP atau SLTA. Pembinaan pasca nikah ini ditujukan pada keluarga yang berusia di bawah 17 tahun. Karena pernikahan dibawah usia 17 tahun masih rentan sekali mendapat cobaan-cobaan dalam kehidupan rumah tangganya sehingga dirasa masih perlu mendapat pembinaan. Ada beberapa fungsi keluarga yaitu sebagai berikut: (Ulfatmi, Hal 21, 2004).

1) Fungsi Pendidikan dalam keluarga hal ini tugas keluarga adalah mendidik dan menyekolahkan anak untuk mempersiapkan kedewasaan dan masa depan anak bila nanti sudah dewasa.

2) Fungsi Sosialisasi tugas keluarga dalam menjalankan fungsi ini adalah bagaimana keluarga mempersiapkan anak menjadi anggota masyarakat yang baik.

3) Fungsi Religius tugas keluarga dalam fungsi ini yaitu memperkenalkan dan mengajak anak dan juga anggota keluarga yang lain dalam kehidupan beragama, dan tugas kepala keluarga untuk menyakinkan bahwa ada kehidupan lain setelah duniawi.

4) Fungsi Perlindungan tugas keluarga dalam fungsi ini adalah melindungi anak dari tindakan-tindakan yang tidak baik itu sangat diperlukan ataupun dibutuhkan supaya anggota keluarga merasa terlindungi dan merasa aman.

5) Fungsi Ekonomi tugas keluarga dalam fungsi ini adalah untuk mencari sumber penghasilan untuk memenuhi kebutuhan keluarga dan pengaturan penggunaan penghasilan keluarga untuk memenuhi kebutuhan keluarga.

6) Fungsi Lingkungan dimana diharapkan keluarga dapat menciptakan kehidupan yang harmonis dalam lingkungan masyarakat sekitar dan alam.

\section{Profil Badan Penasihat Pembinaan dan Pelestarian Perkawinan}

Berdirinya Kantor Urusan Agama di Indonesia berawal dari Departemen Agama melakukan tindakan unifikasi dan sentralisasi secara integral. Kunci utama dalam usaha itu adalah pembentukan Kantor Urusan Agama (KUA). KUA di seluruh daerah sebagai cabang dari kantor pusat nasional yang dibentuk pemerintah.

Kecamatan Panyabungan Selatan adalah kecamatan yang berdiri sejak Tahun 2002 dengan luas wilayah 8.759.72 (Ha) yang sebelumnya merupakan bagian dari Kecamatan panyabungan. Sesuai dengan perma nomor 7 tahun 2002 tentang pemekaran Kecamatan dilingkungan pemerintah Kabupaten Mandailing Natal maka terbentuklah Kecamatan 
Cybernetics: Journal of Research and Educational Studies

Volume 2 Nomor 4, Oktober 2021

Halaman 54-65

Panyabungan Selatan dengan dengan ibukota Kecamatan berada di desa Tanobato. Kecamatan Panyabungan Selatan merupakan pemekaran dari Kecamatan Panyabungan, yang dibagi menjadi 5(lima) bagian, yang terdiri dari :

1. Kecamatan Panyabungan (Induk)

2. Kecamatan Panyabungan Timur

3. Kecamatan panyabungan Utara

4. Kecamatan Panyabungan Barat

5. Kecamatan Panyabungan Selatan

Kecamatan Panyabungan Selatan secara umum merupakan daerah perbukitan yang lebih kurang $600 \mathrm{M}$ di atas permukaan laut, dengan batas wilayah sebagai berikut:

1. Sebelah Utara berbatasan dengan kecamatan Panyabungan dan Kecamatan Panyabungan Barat.

2. Sebelah Timur berbatasan dengan Kecamatan Lembah Sorik Merapi dan Kecamatan Panyabungan.

3. Sebelah Selatan berbatasan dengan Kecamatan Puncak Sorik Merapi dan Kecamatan Batang Natal.

4. Sebelah Barat berbatasan dengan Kecamatan Batang Natal dan Panyabungan Barat.

Kantor Urusan Agama (KUA) adalah unit kerja terdepan. Departemen agama yang melaksanakan sebagaian tugas pemerintah di bidang Agama Islam di wilayah Kecamatan (KUA No. 51712001 dan PMA No. 11/2007, KUA Kecamatan Panyabungan Selatan telah melaksanakan sebagaimana program-program kegiatan berdasarkan Rencana Strategi dan Rencana Kinerja Tahunan.

Adapun tujuan pelaksanaan program meliputi bidang Ketatausahaan, Kepenghuluan, Keuangan NR, Pelaksanaan Bimbingan Manasik Haji, Kemasjidan, Zakat, Wakaf, Keluarga Sakinah, Pangan Halal, Kemitraan Umat dan Bina Ibadah Sosial dengan sasaran program yaitu meningkatkan kualitas pembuatan program kerja dan laporan, meningatkan kualitas pelayanan dan penyelenggaraan bidang kepenghuluan, mening, meningkatkan pemahaman masyarakat tentang keluarga sakinah, meningkatkan pemahaman calon jemaah haji tentang pelaksanaan ibadah haji dan meningkatkan kualitas kehidupan serta meningkatkan konsumen dalam mengkonsumsi pangan halal.

Di dalam pencapaian program telah dilakukan langakah-langkah sebagai berikut:

1. Meningkatkan wawasan dan pemahaman mengenai tugas pokok dan fungsi berdasarkan ketetapan dan peraturan yang berlaku.

2. Meningkatkan profesionalisme dan etos kerja aparatur KUA dalam pelaksanakan tugas pokok.

3. Penggunaan sarana prasarana yang ada secara optimal.

4. Melakukan koordinasi dan sinkronisasi internal maupun eksternal dengan teraarah yang berkaitan dengan tugas, tanggungjawab dan pelayanan kepada masyarakat. 
Cybernetics: Journal of Research and Educational Studies

Volume 2 Nomor 4, Oktober 2021

Halaman 54-65

5. Meningkatkan intensitas penyuluhan dan bimbingan kepada masyarakat di Bidang Urusan Agama Islam.

\section{Tugas Dan Fungsi Bp4}

Pada tahun 1961 diakui bahwa BP4 itu satu-satunya badan yang berusaha dibidang penasehatan perkawinan dan pengurangan perceraian. Tugas dan fungsi pokok BP4 tetap konsisten melaksanakan UU No 1 Tahun 1974 tentang perkawinan, oleh karenanya fungsi dan peran BP4 sangat diperlukan masyarakat dalam mewujudkan kualitas perkawinan (Hasil MUNAS BP4 XIII/2004.)

Adapun visi dan misi Kua Panyabungan Selatan yaitu mewujudkan masyarakat yang beriman dan bertaqwa, berakhlakul karimah serta menghayati nilai-nilai keimanan yang terlihat dalam perilaku sehari-hari dalam kehidupan pribadi, keluarga, bermasyarakat, berbangsa serta bernegara. Sedangkan misinya mengoptimalkan peranannya dalam membentuk keluarga yang sakinah mawaddah warahmah (samawa) dan kehidupan yang beragama (BP4 Pusat, 1995 edisi Mei No. 275, h. 12-13).

Ciri-ciri keluarga ideal atau keluarga sakinah sebagai berikut:

* Berdiri di atas fondasi atau keimanan yang kokoh

* Menunaikan misi ibadah dalam kehidupan

* Mentaati ajaran agama

* Saling mencintai dan menyayangi

* Saling menjaga dan menguatkan dalam kebaikan

* Saling memberikan yang terbaik untuk pasangan

* Musyawarah menyelesaikan masalah

* Membagi peran secara berkeadilan

* Kompak mendidik anak

* Berkontribusi untuk kebaikan masyarakat, bangsa, dan negara.

BP4 didirikan sebagai upaya untuk meningkatkan mutu perkawinan yang didasarkan pada tuntutan agama, yakni suatu perkawinan yang tujuannya tidak hanya sebagai pemuas hawa nafsu dan hanya harta belaka, akan tetapi perkawinan tersebut bertujuan pula terhadap keturunannya dalam arti mencurahkan dan mendidik secara penuh terhadap keturunannya dan juga bertujuan keberuntungan dalam arti bahwa perkawinan tersebut baik dalamsuka maupun duka dirasakan bersama dengan penuh cinta kasih yang suci nan murni.

\section{Anggaran Dasar BP4 :}

1. Memberikan nasihat dan penerangan tentang soal-soal nikah, talak cerai dan rujuk kepada yang akan melakukannya serta khalayak ramai.

2. Mengurangi terjadinya perceraian dan poligami.

3. Memberikan bantuan dalam menyelesaikan kesulitan-kesulitan perkawinan dan perselisihan rumah tangga menurut hukum agama.

4. Menerbitkan buku-buku atau brosur-brosur dan menyelenggarakan kursuskursus, pentaran, diskusi, seminar dan sebagainya.

5. Bekerjasama dengan lembaga-lembaga yang bersamaan tujuannya.

6. Lain-lain usaha yang dipandang bermanfaat 
Cybernetics: Journal of Research and Educational Studies

Volume 2 Nomor 4, Oktober 2021

Halaman 54-65

Untuk mencapai tujuan dan fungsi maka BP4 mempunyai upaya dan usaha, sebagaimana dituangkan dalam AD/ART BP4 sebagai berikut:

1. Memberikan bimbingan, penasehatan, dan penerangan NTCR kepada masyarakat baik perorangan maupun kelompok.

2. Memberikan bimbingan tentang peraturan perundang-undangan yang berkaitan dengan keluarga.

3. Memberikan bantua mediasi kepada para pihak yang berperkara di pengadilan agama.

4. Memberikan bantuan advokasi dalam mengatasi masalah perkawinan, keluarga dan perselisihan rumah tangga di peradilan agama.

5. Menurunkan terjadinya perselisihan serta perceraian, poligami yang tidak bertanggung jawab, pernikahan dibawah umur dan pernikahan yang tidak tercatat.

6. Bekerjasama dengan instansi, lembaga organisasi yang memiliki kesamaan tujuan baik di dalam maupun di luar negeri.

7. Menyelenggarakan kursus calon pengantin, penataran atau pelatihan, diskusi, seminar, dan kegiatan-kegiatan sejenis yang berkaitan dengan perkawinan dan keluarga.

8. Menyelenggarakan pendidikan keluarga untuk peningkatan penghayatan dan pengalaman nilai-nilai keimanan, ketaqwaan dan akhlakul karimah dalam rangga membina keluarga sakinah.

9. Berperan aktif dalam kegiatan lintas sektoral yang bertujuan membina keluarga sakinah.

10. Meningkatkan upaya pemberdayaan ekonomi keluarga.

Upaya dan usaha tersebut di atas merupakan rangkaian upaya dan usaha yang dilakukan BP4 untuk mewujudkan keluarga sakinah mawaddah rahmah. Dalam pelaksanaannya upaya dan usaha tersebut dilaksanakan di berbagai program yang ada di BP4 itu sendiri. Serta dapat memberikan penasehatan dan membantu mengarahkan calon pasangan untuk memperoleh solusi untuk mengatasi problem keluarga, perselisihan yang terjadi dalam keluarga sedapat mungkin dibantu upaya penyelesaiannya agar tidak berlarut-larut

\section{Tanggapan / Hasil Kerja Bp4}

Dari hasil kerja sama semua pihak yang berada di dalam kantor Bp4 Kua Panyabungan Selatan ini dapat memabantu masyarakat dalam aspek yang berhubungan dengan kekeluargaan terutama dalam rumah tangga dan membentuk keluarga sakinah di wilayah tersebut. BP4 merupakan salah satu organisasi yang berperan sebagai mitra kerja Kementrian Agama yang bersifat profesional dan yang bertujuan untuk mempertinggi mutu perkawinan dan mewujudkan keluarga sakinah dan kekal menurut ajaran Islam. Dengan adanya BP4 maka calon pasangan dipermudah untuk mengetahui atau mendapatkan ilmu pengetahuan tentang bagaimana cara menjadi keluarga yang sakinah mawaddah rahmah. Tujuan dibentuknya BP4 untuk mempertinggi dan penerangan mengenai mutu perkawinan guna mewujudkan 
Cybernetics: Journal of Research and Educational Studies

Volume 2 Nomor 4, Oktober 2021

Halaman 54-65

keluarga sakinah menurut ajaran Islam untuk mencapai masyarakat dan bangsa yang maju, mandiri, bahagia sejahtera maupun spiritual.

Hasil kerjanya Bp4 di Kua sebagai berikut:

Meningkatkan kualitas perkawinan dan kehidupan berkeluarga yang sakinah, mawaddah rahmah.

Menurunkan angka perceraian dengan meningkatkan pelayanan terhadap keluarga bermasalah melalui kegiatan konseling, mediasi dan advokasi.

Menguatkan kapasitas kelembagaan dan SDM (Sumber Daya Manusia) BP4 dalam rangka mengoptimalkan program dan mencapai tujuan.

Memberikan penyuluhan tentang peraturan perundang-undangan yang berkaitan dengan keluarga.

Mengembangkan jaringan kemitraan dengan instansi atau lembaga yang memiliki misi dan tujuan yang sama.

Kaitan BP4 dengan perkawinan adalah memberikan penasehatan melakukan pembinaan dan membantu dalam pelestarian perkawinan. BP4 juga sebagai wadah atau lembaga konsultasi dan mediasi terhadap pasangan suami istri yang menghadapi masalah rumah tangga. BP4 lewat peran seorang konsultannya memberikan penasehatan dan membantu mengarahkan calon pasangan untuk memperoleh solusi untuk mengatasi problem keluarga, perselisihan yang terjadi dalam keluarga sedapat mungkin dibantu upaya penyelesaiannya, sehingga tidak berlarut-larut dan tidak berakhir dengan perceraian (Anggaran Dasar / Anggaran Rumah Tangga BP4).

\section{Tanggapan Masyarakat Terhadap Peran Bp4}

Badan Penasihataan Pembinaan dan Pelestarian Perkawinan biasa disingkat dengan BP4 adalah organisasi perkumpulan yang bersifat sosial keagamaan sebagai mitra kementerian agama dan isntansi terkait lain dalam upaya meningkatkan kualitas perkawinan umat islam di Indonesia membina dan mengayomi keluarga muslimin di Indonesia. Bp4 berdiri secara resmi pada tanggal 3 januari 1961 di Jakarta, Indonesia berdasarkan pada SK menteri agama RI no.851961 yang menetapkan kepengurusan Bp4 (Drs. H. Anwar Saadi, 2019). Masyarakat sangat memerlukan peran Bp4 (Badan Penasihatan Pembinaan dan Pelestarian Perkawinan) karena bisa mengatur perkawinan dan mengurus segala suatu yang diperlukan termasuk dalam membangun suatu rumah tangga, memberikan bimbingan, ceramah dalam hal pernikahan. Bp4 di kantor urusan agama (KUA) Panyabungan Selatan memberikan dampak negatif bagi masyarakat sekitar.

\section{KESIMPULAN}

Keluarga adalah bentuk lembaga paling kecil dalam kehidupan masyarakat. Melalui keluarga, nilai - nilai dan ajaran agama bisa diwariskan dan diamalkan sebagaimana yang disyariatkan oleh agama islam. Indikator keluarga baik yang harmonis dan sejahtera dalam islam sebenarnya cukup sederhana. Yaitu sakinah, mawaddah, wa rahmah. Akan tetapi, dibutuhkan usaha dan kerja sama untuk bisa meraih hal tersebut. Berdasarkan hasil penelitian yang telah diuraikan, dapat 
Cybernetics: Journal of Research and Educational Studies

Volume 2 Nomor 4, Oktober 2021

Halaman 54-65

disimpulakan bahwa: BP4 yaitu kepanjangan dari Badan Penasihatan Pembinaan dan Pelestarian Perkawinan. BP4 adalah sebuah lembaga yang merupakan pelaksana atau pengemban tugas-tugas kementrian Agama dalam upaya membantu setiap pasangan calon pengantin untuk mewujudkan keluarga sakinah mawaddah wa rahmah. Tujuan dibentuknya tidak lain yaitu untuk mempertinggi mutu perkawinan dan meminimalisir angka perceraian yang setiap tahun mengalami peningkatan.

Hal ini sejalan atau sesuai dengan tujuan pernikahan menurut undang-undang (UU) yaitu membentuk keluarga atau rumah tangga yang bahagia dan kekal berdasarkan ketuhanan Yang Maha Esa. Keluarga sakinah adalah keluarga dengan penuh kebahagiaan yang terlahir dari usaha keras pasangan suami istri dalam memenuhi semua kewajiban, baik kewajiban perorangan maupun kewajiban bersama. Ciri-ciri dari sebuah keluarga sakinah diantaranya yaitu keluarga yang selalu ridha terhadap anugrah yang diberikan Allah Swt. Jika diberi lebih mereka bersyukuar, jika kekurangan mereka sabar dan terus berikhtiyar. Mereka keluaraga yang senantiasa berusaha untuk memperbaiki semua aspek kehidupan mereka dengan wajib menuntut ilmi-ilmu agama Allah Swt.

Peranan BP4 di KUA Kecamatan Panyabungan Selatan memiliki program kerja untuk membimbing calon pengantin yang dilaksanakan oleh Bp4 Kua Kecamatan Panyabungan Selatan di hari kerja tergantung ada tidaknya calon pengantin yang akan mengikuti kursus calon pengantin karena tidak semua calon pengantin mau mengikuti kursus calon pengantin. Kursus calon Pengantin dilaksanakan melalui proses melengkapi pendaftaran calon pengantin kemudian dilaksanakan dengan menggunakan metode ceramah, tanya jawab dan pelatihan ijab qabul.

\section{DAFTAR PUSTAKA}

Macgrus, Adib. Fondasi Keluarga Sakinah, Jakarta: Subdit Bina Keluarga Sakinah, 2019. Rahima. Modul Pendidikan Keluarga Sakinah, Jakarta: Depaq RI, 2009.

Sarong, Hamid. Hukum Perkawinan Islam di Indonesia, Banda Aceh :Divisi penerbitan,2004.

Basyir, A.Azhar. Hukum Perkawinan Islam, cet IX. Yogyakarta: UII Press,1991.

Hasan, Ali. Pedoman Hidup Berumah Tangga dalam Islam, Jakarta: press

Buku UU Perkawinan 1974 Negara Republik Indonesia bab I pasal I.

Hidayat, Yusuf. Panduan Pernikahan Islami,Guepedia Publisher,2019.

Hermawati, Nunik. Menikah untuk Bahagia, Jakarta Selatan: Mizan Digital, 2018.

Al-Mazhari, Mahmud. Bekal Pernikahan, Jakarta: Qisthi Press,2010.

Januar, Iwan. Tips Meraih Pernikahan Sakinah, Jakarta: Mediati, cet I, 2016.

Al-Mazhari, Mahmud, Perkawinan Idaman, Jakarta: Qisthi Press, 2010.

ASM, Syaifuddin, Membangun Keluarga Sakinah, Tanggerang: Agromedia Pustaka, 2013. 
Cybernetics: Journal of Research and Educational Studies

Volume 2 Nomor 4, Oktober 2021

Halaman 54-65

Dipetik, dari www.dalamislam.com:http://dalamislam.com/hukum-islam-

/pernikahan// keluarga-sakinah- mawaddah-wa-rahmah Mishba. (2015).

Dipetik dari www.mishba7.com: http://mishba7.com/2015/10/pengertian-sakinahmawaddah-warahmah- pernikahan.html?m=1 Takariawan, C. (2015, April 02).

Subhan Zaituna, Membina Keluarga Sakinah., Yogyakarta: Pustaka Pesantren, 2004. 